\title{
RASIO CAMPURAN AIR KELAPA SARI WORTEL DAN VARIASI SUSU SKIM TERHADAP MUTU MINUMAN PROBIOTIK
}

\section{THE RATIO OF COCONUT WATER, CARROT JUICE, AND VARIETY OF SKIM MILK MIXTURE ON PROBIOTIC DRINK QUALITY}

\author{
Judith Henny Mandei, Mariati Edam, Yunita Filia Assah \\ Balai Riset dan Standardisasi Industri Manado \\ Jalan Diponegoro No: 21-22 Manado, telp/fax. (0431) 852395, 852396 \\ Email: nenimandei@yahoo.com
}

Diterima : 29-05-2019

Direvisi : 10-07-2019

Disetujui : 17-09-2019

\begin{abstract}
ABSTRAK
Efek menguntungkan probiotik pada kesehatan manusia semakin dipromosikan oleh para profesional kesehatan. Penelitian bertujuan untuk melihat pengaruh rasio air kelapa sari wortel dan susu skim serta mendapatkan minuman probiotik campuran air kelapa dan sari wortel yang memenuhi syarat mutu sesuai SNI 7552:2009 Minuman susu fermentasi berperisa. Penelitian dilakukan menggunakan metode percobaan faktorial dengan perlakuan rasio air kelapa sari wortel (b/b) yaitu 100:0; 90:10; 80:20, dan penambahan susu skim (b/b) yaitu: $0 \% ; 1 \% ; 2 \%$ dan $3 \%$. Pengamatan dilakukan terhadap bahan baku air kelapa dan wortel meliputi kadar gula, mineral, dan kadar protein susu skim, dan produk minuman probiotik meliputi kadar lemak, padatan tanpa lemak, protein, abu, keasaman tertitrasi, jumlah kultur starter dan pengamatan organoleptik sesuai SNI 7552:2009 Minuman Susu Fermentasi Berperisa, serta kandungan mineral. Hasil penelitian menunjukkan bahwa produk yang memenuhi syarat mutu adalah produk minuman campuran air kelapa sari wortel 80:20 dan susu skim 1\% sehingga menjadi produk terbaik dengan kandungan lemak $0,50 \%$, padatan susu tanpa lemak $19,72 \%$, protein $1,10 \%$, abu $0,68 \%$, keasaman tertitrasi $0,8 \%$, jumlah kultur starter $2,80 \times 10^{9}$, dengan penampakan cair, bau khas yogurt dan wortel, rasa asam khas yogurt dan rasa wortel, namun kurang homogen.
\end{abstract}

Kata kunci : Air kelapa, minuman probiotik, sari wortel.

\section{ABSTRACT}

The beneficial effects of probiotics on human health are increasingly promoted by health professionals. The research aims to see the effect of the ratio of coconut water, carrot juice and the addition of skim milk and get a probiotic beverage mixture of coconut water and carrot juice that meets the quality requirements SNI 7552:2009 Flavored fermented milk drinks. The study was conducted using the factorial experimental method with treatment of ratio of coconut water vs carrot juice in b/b (100: 0 ; 90:10; 80:20), and the addition of skim milk (b/b), namely: 0\%; 1\%; 2\% and 3\%. Observations were made on raw materials of coconut water and carrot juice including sugar, mineral content and protein content of skim milk. Probiotic drinks was testing on its fat content, nonfat solids, protein, ash, titrated acidity, number of starter cultures and organoleptic observations according to SNI 7552:2009 Fermented Milk Drinks, and mineral content. The results showed that the products that met the quality requirements were 80:20 coconut carrot juice mixed products and 1\% skim milk so that it became the best product with $0.50 \%$ fat content, $19.72 \%$ nonfat solid milk, 1.10 protein $\%$, ash $0.68 \%$, acidity titrated $0.8 \%$, number of starter cultures $2.80 \times 10^{\circ}$, with liquid appearance, distinctive smell of yogurt and carrots, sour taste typical of yogurt + carrot flavor, but less homogeneous.

Keywords : Carrot juice, coconut water, functional drink 


\section{PENDAHULUAN}

ulawesi Utara merupakan daerah penghasil kelapa yang cukup potensial. Luas areal tanaman kelapa tahun 2017 adalah 281.563,73 Ha dengan produksi sebesar 255.880,39 ton (Kristiningsih et al, 2018). Tanaman kelapa dikenal sebagai pohon kehidupan karena semua bagian tanamannya dapat dimanfaatkan termasuk air kelapa.

Air kelapa merupakan $25 \%$ dari komponen buah kelapa. Air kelapa muda mengandung air $95,50 \%$, protein $0,10 \%$, lemak kurang dari $0,10 \%$, karbohidrat $4,00 \%$, dan abu $0,40 \%$. Air kelapa muda juga mengandung vitamin $C$ sebesar 2,20-3,40 mg/100 ml dan vitamin B kompleks yang terdiri atas asam nikotinat, asam pantotenat, biotin, asam folat, vitamin $\mathrm{B} 1$, dan sedikit piridoksin. Air kelapa muda juga mengandung sejumlah mineral yaitu nitrogen, fosfor, kalium, magnesium, klorin, sulfur, dan besi (Yanuar dan Sutrisno, 2015).

Selain tanaman kelapa Sulawesi Utara juga menghasilkan tanaman sayuran seperti wortel. Kabupaten Minahasa Selatan dan Kabupaten Bolaang Mongondow Timur merupakan penghasil terbesar sayuran wortel. Tahun 2014, luas panen tanaman wortel adalah $1.815 \mathrm{Ha}$ dengan produksi sebesar $186.366 \mathrm{Ku}$ dan rata-rata produksi 102,68 Ku/Ha (Badan Pusat Statistik, 2015). Umbi wortel merupakan sumber vitamin A yang mengandung karoten. Karoten merupakan pigmen isomerik berwarna violet-merah-kuning (jingga) dikenal sebagai provitamin A. Manfaat provitamin A, selain terhadap kesehatan mata juga sebagai antioksidan alami yang dapat mencegah beberapa penyakit antara lain penyakit jantung, kanker, fungsi imun dan artritis (Zubaidah et al., 2005).

Kemajuan teknologi dan informasi khususnya di dunia pangan membuat masyarakat mengonsumsi makanan tidak hanya untuk sekedar rasa kenyang saja, namun mulai bermunculan alasan-alasan lain. Saat ini, masyarakat mulai memilih untuk mengonsumsi jenis makanan yang dapat memberikan manfaat kesehatan bagi tubuh mereka. Makanan yang memiliki manfaat lain bagi tubuh, selain kandungan zat gizi yang dimilikinya disebut sebagai pangan fungsional. Salah satu jenis pangan fungsional adalah pangan yang memiliki bakteri hidup yang menguntungkan bagi kesehatan dalam jumlah yang memadai (probiotik).

Probiotik didefinisikan sebagai mikroorganisme hidup dengan pengaruh positif pada inangnya dengan kemampuan untuk meningkatkan keseimbangan mikroba usus (Lebaka et al., 2018). Sedangkan menurut Farnworth dan Champagne (2015) probiotik adalah mikroorganisme hidup yang bila diberikan dalam jumlah yang memadai memberikan manfaat kesehatan bagi inangnya. Minuman probiotik adalah minuman fermentasi asam laktat yang mengandung bakteri asam laktat hidup dan dapat memberikan efek kesehatan ketika dikonsumsi. Efek menguntungkan dari produk probiotik (makanan dengan tambahan mikroba hidup) pada kesehatan manusia semakin dipromosikan oleh para profesional kesehatan. Telah diamati bahwa probiotik dapat memainkan peran penting pada metabolisme dan meningkatkan fungsi kekebalan, juga bisa memiliki efek yang signifikan dalam mengurangi penyakit menular pada anak-anak (Lebaka et al., 2018).

Beberapa penelitian tentang minuman probiotik baik dari air kelapa maupun wortel secara fermentasi telah dilakukan, namun minuman probiotik yang diperoleh dari campuran air kelapa dan wortel belum pernah dilakukan. Penelitian ini dilaksanakan sebagai upaya untuk mendapatkan minuman yang kaya gizi, dilihat dari kandungannya air kelapa memiliki nutrisi cukup lengkap, namun tidak mengandung provitamin A yang dapat diperoleh/diperkaya dari kandungan provitamin A yang ada dalam umbi wortel. Selain itu air kelapa dan sari wortel memiliki potensi yang cukup baik untuk dibuat menjadi minuman probiotik yang berfungsi untuk kesehatan sehingga dapat dikategorikan sebagai minuman fungsional. Minuman probiotik campuran air kelapa dan sari wortel menggunakan kultur starter bakteri asam laktat probiotik yang diperoleh dari minuman komersil yakult yang mengandung kultur hidup Lactobacillus casei strain Shirota. 
Dalam pembuatan minuman fermentasi jenis yogurt dibutuhkan susu skim. Susu skim merupakan susu yang sebagian besar lemaknya dihilangkan. Menurut Ginting dan Pasaribu (2005), susu skim merupakan susu dengan protein tinggi yang sering digunakan dalam pembuatan yogurt. Susu skim adalah bagian dari susu yang tertinggal setelah lemak dipisahkan melalui proses separasi. Laktosa yang terkandung dalam susu skim sekitar $5 \%$ dengan $\mathrm{pH} 6,6$. Laktosa merupakan karbohidrat utama dalam susu yang digunakan oleh bakteri starter sebagai sumber energi untuk pertumbuhannya (Krisnaningsih dan Efendi, 2015).

Berdasarkan hal ini maka dilakukan penelitian pembuatan minuman probiotik campuran air kelapa dan sari wortel secara fermentasi menggunakan bakteri asam laktat Lactobacillus casei dengan variasi rasio air kelapa sari wortel dan susu skim. Penelitian ini bertujuan untuk melihat pengaruh rasio air kelapa sari wortel dan susu skim serta mendapatkan minuman probiotik campuran air kelapa sari wortel yang memenuhi syarat mutu sesuai SNI 7552:2009 untuk minuman susu fermentasi berperisa tanpa perlakuan panas setelah fermentasi (Badan Standardisasi Nasional, 2009).

\section{METODE PENELITIAN}

\section{Waktu dan Tempat}

Penelitian ini dilaksanakan pada bulan April-Oktober tahun 2017 di Balai Riset dan Standardisasi Industri Manado.

\section{Bahan dan Alat}

Bahan-bahan yang digunakan dalam penelitian ini terdiri dari air kelapa, wortel, gula pasir (sukrosa), susu skim, yakult, biokul plain, kemasan botol plastik, dan bahan-bahan untuk pengujian laboratorium.

Alat-alat yang digunakan terdiri dari panci stainless steel, loyang plastik, gelas ukur, juice ekstraktor, mixer, kompor, pengaduk, termometer, talenan, timbangan, dan peralatan untuk pengujian laboratorium.

\section{Metode Penelitian}

Penelitian menggunakan Rancangan Acak Lengkap faktorial 2 (dua) kali ulangan. Yang menjadi perlakuan adalah:

1. Perbandingan air kelapa dan sari wortel (v/v), terdiri dari 100:0; 90:10 dan 80:20.

2. Level penambahan susu skim (\%, b/v), terdiri dari: $0 ; 1 ; 2$ dan $3 \%$.

\section{Prosedur Penelitian}

Air kelapa disaring dan dipasteurisasi pada suhu $80^{\circ} \mathrm{C}$ selama 10 menit. Wortel dikupas, dicuci, dipotong-potong kemudian diblansing selama 10 menit. Setelah itu wortel yang sudah dipotong-potong diambil sarinya menggunakan juice ekstraktor. Air kelapa dan sari wortel ditimbang dan dicampur sesuai perbandingan perlakuan. Susu skim (sesuai perlakuan) dan gula pasir $10 \%(\mathrm{~b} / \mathrm{b})$ ditambahkan ke campuran air kelapa sari wortel kemudian dihomogenisasi. Seluruh campuran dipanaskan pada suhu $80^{\circ} \mathrm{C}$ selama 10 menit, selanjutnya suhu diturunkan sampai $37^{\circ} \mathrm{C}$. Campuran air kelapa sari wortel yang sudah diperlakukan sebagaimana di atas, ditambahkan kultur starter sebanyak 3\% kemudian diaduk dan dituang ke dalam wadah-wadah botol plastik dan diinkubasi pada suhu $27^{\circ} \mathrm{C}$ selama 24 jam. Minuman probiotik hasil fermentasi air kelapa dan sari wortel siap dianalisa. Produk disimpan pada refrigerator suhu $\pm 5^{\circ} \mathrm{C}$. 


\section{Variabel yang diamati}

Pengamatan dilakukan terhadap bahan baku air kelapa dan wortel meliputi kadar gula (metode Luff-Schoor), kadar mineral yaitu fosfor, klorida, kalium, natrium, kalsium, magnesium dan besi (metode kolorimetri menggunakan Atomic Absorption Spektrophotometry) serta kadar protein dari susu skim menggunakan metode makro Kjeldahl.

Produk minuman probiotik campuran air kelapa dan wortel meliputi keasaman tertitrasi, kadar lemak, protein, padatan tanpa lemak, kadar abu, dan jumlah mikroba kultur starter dan pengamatan organoleptik (penampakan, bau, rasa dan homogenitas) sesuai SNI 7552:2009 Minuman susu fermentasi berperisa (Badan Standardisasi Nasional, 2009). Dilakukan juga pengujian kandungan mineral $(\mathrm{K}, \mathrm{Na}, \mathrm{Ca}, \mathrm{Mg}, \mathrm{Fe})$ produk minuman probiotik dengan metode kolorimetri menggunakan AAS.

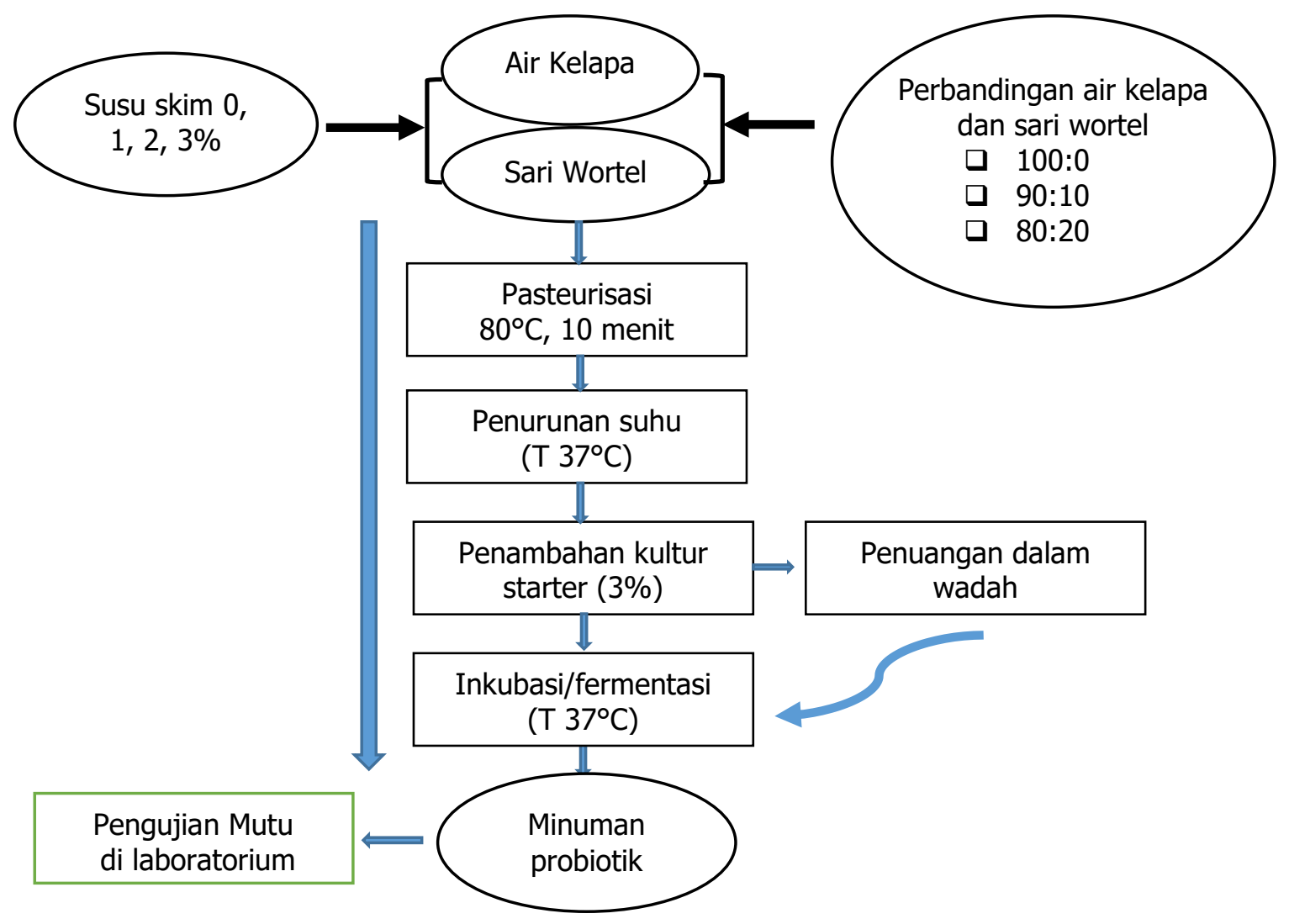

Gambar 1. Flow Chart Pembuatan Minuman Probiotik Campuran Air Kelapa dan Sari Wortel

\section{Analisis Data}

Data yang diperoleh dianalisis varians dilanjutkan dengan uji perbandingan Tukey menggunakan software Minitab 14.

\section{HASIL DAN PEMBAHASAN \\ Bahan Baku}

Hasil pengujian bahan baku yang digunakan dalam pembuatan minuman probiotik campuran air kelapa dan sari wortel dapat dilihat pada Tabel 1. Dari Tabel 1 terlihat bahwa baik air kelapa maupun sari wortel mengandung sejumlah mineral yang cukup, dengan kandungan gula yang memberikan rasa manis khas pada produk. Secara alami air kelapa memiliki komposisi mineral dan gula yang seimbang sehingga mempunyai kesetimbangan elektrolit yang sama dengan cairan tubuh manusia. Jika ditelusuri susunan komposisi gizi dari 
jenis-jenis susu formula maka hampir semua komposisi makro maupun mikronutrien pada air kelapa muda terkandung pada susu formula (Rindengan et al., 2007). Kandungan magnesium pada wortel juga membantu mengontrol kolesterol dalam tubuh (Harjana, 2013). Selain wortel ternyata air kelapa muda juga mengandung magnesium sebesar 1227 ppm yang hampir sama jumlahnya dengan wortel (1277 ppm).

Tabel 1. Hasil Pengujian Bahan Baku Minuman Fungsional Campuran Air Kelapa dan Sari Wortel.

\begin{tabular}{|c|c|c|c|c|c|}
\hline \multirow[b]{2}{*}{ No. } & \multirow{2}{*}{ Parameter } & \multicolumn{3}{|c|}{ Jenis Bahan } & \multirow{2}{*}{ Satuan } \\
\hline & & Wortel & Air Kelapa & Susu Skim & \\
\hline 1. & Kadar gula & 2,94 & 2,86 & - & $\%$ \\
\hline 2. & Fosfor & 23 & $\mathrm{ttd}$ & - & ppm \\
\hline 3. & Klorida & $\mathrm{ttd}$ & 7600 & - & $\mathrm{ppm}$ \\
\hline 4. & K & 5459,94 & 3298,38 & - & ppm \\
\hline 5. & $\mathrm{Na}$ & 395,65 & 381,32 & - & ppm \\
\hline 6. & $\mathrm{Ca}$ & 582,59 & 617,73 & - & $\mathrm{ppm}$ \\
\hline 7. & $\mathrm{Mg}$ & 1277 & 1227 & - & $\mathrm{ppm}$ \\
\hline 8. & $\mathrm{Fe}$ & 19,78 & 14.30 & - & ppm \\
\hline 9. & Protein & - & - & 34,84 & $\%$ \\
\hline
\end{tabular}

Ket.: Untuk Susu skim hanya dilakukan pengujian kadar protein

Produk Minuman Fungsional

Hasil pengujian pengaruh rasio air kelapa sari wortel dan susu skim terhadap mutu produk minuman probiotik campuran air kelapa dan sari wortel dapat dilihat pada Tabel 2 .

Tabel 2. Hasil Pengujian Pengaruh Rasio Air Kelapa Sari Wortel dan Susu Skim terhadap Mutu Produk Minuman Probiotik Campuran Air Kelapa dan Sari Wortel

\begin{tabular}{|c|c|c|c|c|c|c|c|}
\hline \multicolumn{2}{|c|}{ Perlakuan } & \multirow{2}{*}{\multicolumn{2}{|c|}{ 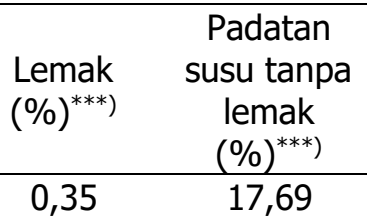 }} & \multirow{2}{*}{$\begin{array}{c}\text { Protein } \\
\left.(\%)^{* * *}\right)\end{array}$} & \multirow{2}{*}{$\begin{array}{c}\begin{array}{c}\text { Abu } \\
\left.(\%)^{* * *}\right)\end{array} \\
0,52\end{array}$} & \multirow{2}{*}{$\begin{array}{c}\text { Keasaman } \\
\begin{array}{c}\text { Tertitrasi } \\
\left.(\%)^{* *}\right)\end{array} \\
0,32^{\mathrm{a}}\end{array}$} & \multirow{2}{*}{$\begin{array}{c}\begin{array}{c}\text { Jumlah Kultur } \\
\text { Starter } \\
\text { (koloni/ml) }^{* * *} \text { ) }\end{array} \\
1,43 \times 10^{9}\end{array}$} \\
\hline Air & Susu skim $0 \%$ & & & & & & \\
\hline kelapa:Sari & Susu skim $1 \%$ & 0,40 & 17,78 & 0,42 & 0,53 & $0,61^{\mathrm{bc}}$ & $4,7 \times 10^{9}$ \\
\hline wortel & Susu skim 2 \% & 0,45 & 18,49 & 0,60 & 0,56 & $0,69^{b c}$ & $4,51 \times 10^{9}$ \\
\hline$(100: 0)$ & Susu skim $3 \%$ & 0,60 & 18,94 & 0,81 & 0,67 & $0,69^{b c}$ & $4,95 \times 10^{9}$ \\
\hline Air & Susu skim $0 \%$ & 0,50 & 17,76 & 0,42 & 0,53 & $0,42^{\mathrm{ab}}$ & $1,72 \times 10^{9}$ \\
\hline Kelapa:Sari & Susu skim $1 \%$ & 0,73 & 18,29 & 0,83 & 0,61 & $0,69^{b c}$ & $2,91 \times 10^{9}$ \\
\hline wortel & Susu skim 2 \% & 0,76 & 19,03 & 1,05 & 0,70 & $0,84^{\text {cde }}$ & $3,44 \times 10^{9}$ \\
\hline$(90: 10)$ & Susu skim $3 \%$ & 0,76 & 19,60 & 1,23 & 0,78 & $0,91^{\mathrm{de}}$ & $4,23 \times 10^{9}$ \\
\hline Air & Susu skim 0 \% & 0,40 & 18,24 & 0,41 & 0,58 & $0,57^{b}$ & $2,24 \times 10^{9}$ \\
\hline kelapa:Sari & Susu skim $1 \%$ & 0,50 & 19,72 & 1,10 & 0,68 & $0,80^{\text {cd }}$ & $2,80 \times 10^{9}$ \\
\hline Wortel & Susu skim 2 \% & 0,50 & 20,13 & 1,64 & 0,78 & $0,94^{\text {de }}$ & $3,68 \times 10^{9}$ \\
\hline$(80: 20)$ & Susu skim $3 \%$ & 0,61 & 20,15 & 1,66 & 0,79 & $1,04^{e}$ & $7,7 \times 10^{9}$ \\
\hline \multicolumn{2}{|c|}{$\left(\right.$ SNI 7552:2009) ${ }^{*}$} & $\begin{array}{l}\text { maks. } \\
0,5 \%\end{array}$ & $\min .3 \%$ & $\min .1 \%$ & $\begin{array}{c}\text { maks. } \\
1 \%\end{array}$ & $0,2-0,9 \%$ & $\begin{array}{c}\min .1 \times 10^{6} \\
\text { koloni/ml }\end{array}$ \\
\hline
\end{tabular}




\section{Kadar Lemak}

Dari Tabel 2 dapat dilihat bahwa rata-rata kadar lemak minuman probiotik campuran air kelapa sari wortel yang dibuat dengan variasi penambahan susu skim berkisar antara 0,35$0,76 \%$. Setelah dilakukan analisis varians interaksi perlakuan rasio air kelapa sari wortel dan penambahan susu skim wortel tidak memberikan pengaruh nyata $(p>0.05)$ terhadap kadar lemak minuman probiotik. Hal ini berarti secara statistik tidak ada perbedaan yang nyata kadar lemak dari produk minuman probiotik baik yang ditambahkan sari wortel maupun yang $100 \%$ air kelapa dikombinasikan dengan penambahan susu skim 0, 1, 2 dan 3\%. Hal ini disebabkan bahan baku air kelapa dan sari wortel keduanya memiliki kandungan lemak yang sangat kecil sehingga tidak secara nyata mempengaruhi produk minuman yang dihasilkan. Demikian juga dengan susu yang digunakan dalam pembuatan minuman probiotik tidak mengandung atau sedikit sekali mengandung lemak. Air kelapa mengandung lemak 0,1 g/100 g, dan wortel mengandung lemak sebanyak 0,6 g/100 g ('Data Komposisi Pangan Indonesia - Beranda', 2017). Sedangkan menurut Ginting and Pasaribu (2005), susu skim adalah bagian dari susu yang tertinggal setelah lemak dipisahkan melalui proses separasi. Hal ini sejalan dengan yang dinyatakan dalam Mandei (2016) bahwa bahan dasar susu yang digunakan akan mempengaruhi mutu produk. Pengaruh interaksi perlakuan rasio air kelapa sari dan interaksi perlakuan rasio air kelapa sari wortel dan penambahan susu skim terhadap kadar lemak minuman probiotik dapat dilihat pada Gambar 2.

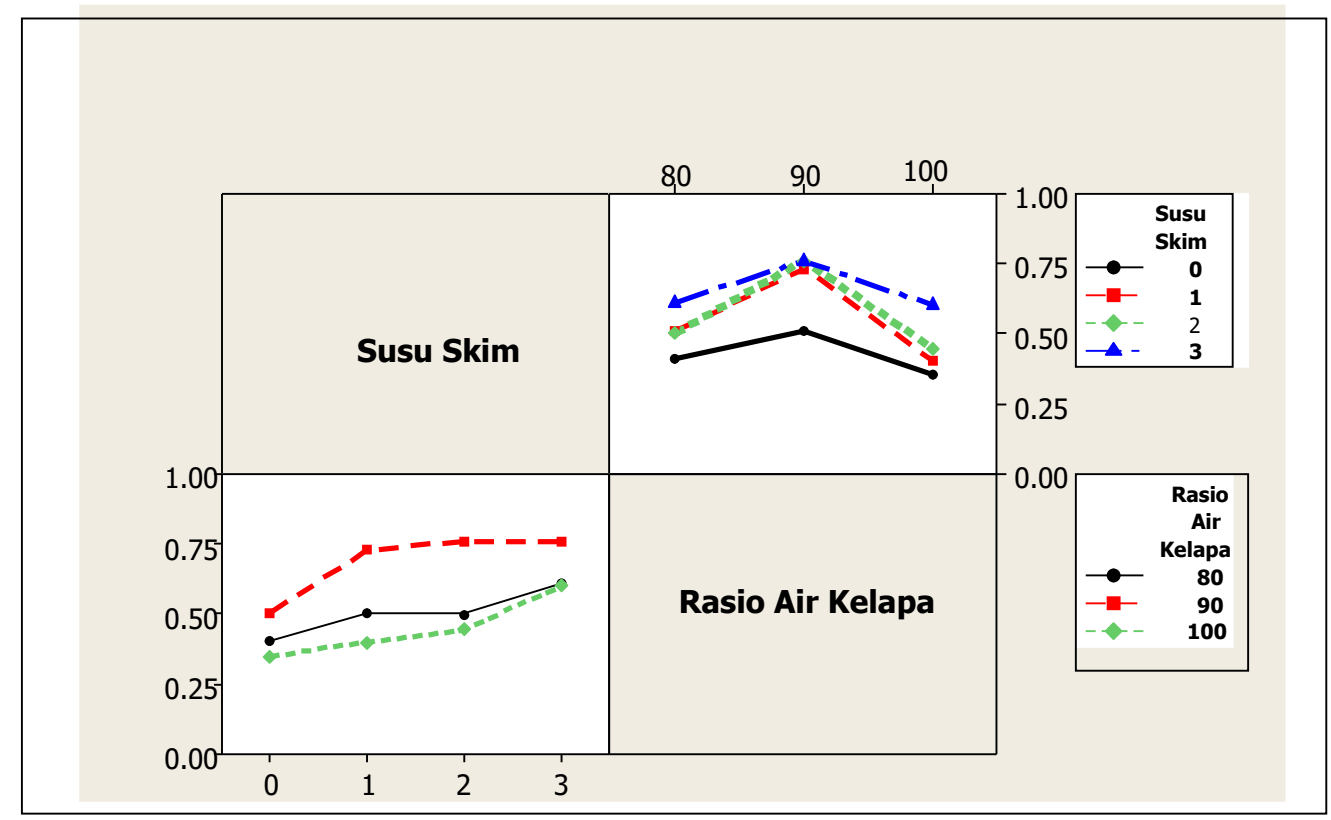

Gambar 2. Pengaruh Rasio Air kelapa Sari wortel dan Penambahan Susu Skim terhadap Kadar Lemak Minuman Probiotik

Dari Gambar 2 terlihat bahwa semakin tinggi prosentase penambahan susu skim cenderung meningkatkan kandungan lemak dari produk minuman. Kandungan lemak dari produk minuman dengan perlakuan rasio air kelapa sari wortel 100:0, susu skim 3\%; perlakuan rasio air kelapa sari wortel 90:10, susu skim 1, 2, 3\% dan perlakuan rasio air kelapa sari wortel 80:20, susu skim 3\% tidak memenuhi syarat mutu SNI 7552:2009 karena kadar lemak melebihi persyaratan yaitu maksimum 0,5\%. 


\section{Padatan Susu tanpa Lemak}

Hasil pengujian rata-rata kadar padatan susu tanpa lemak produk minuman probiotik campuran air kelapa dan sari wortel berkisar antara 17,69-20,15\% dapat dilihat pada Tabel 2. Setelah dilakukan analisis varians interaksi kedua perlakuan tidak memberikan pengaruh yang nyata $(p>0,05)$. Pengaruh rasio air kelapa sari wortel dan penambahan susu skim terhadap kadar padatan susu tanpa lemak minuman probiotik dapat dilihat pada Gambar 3.

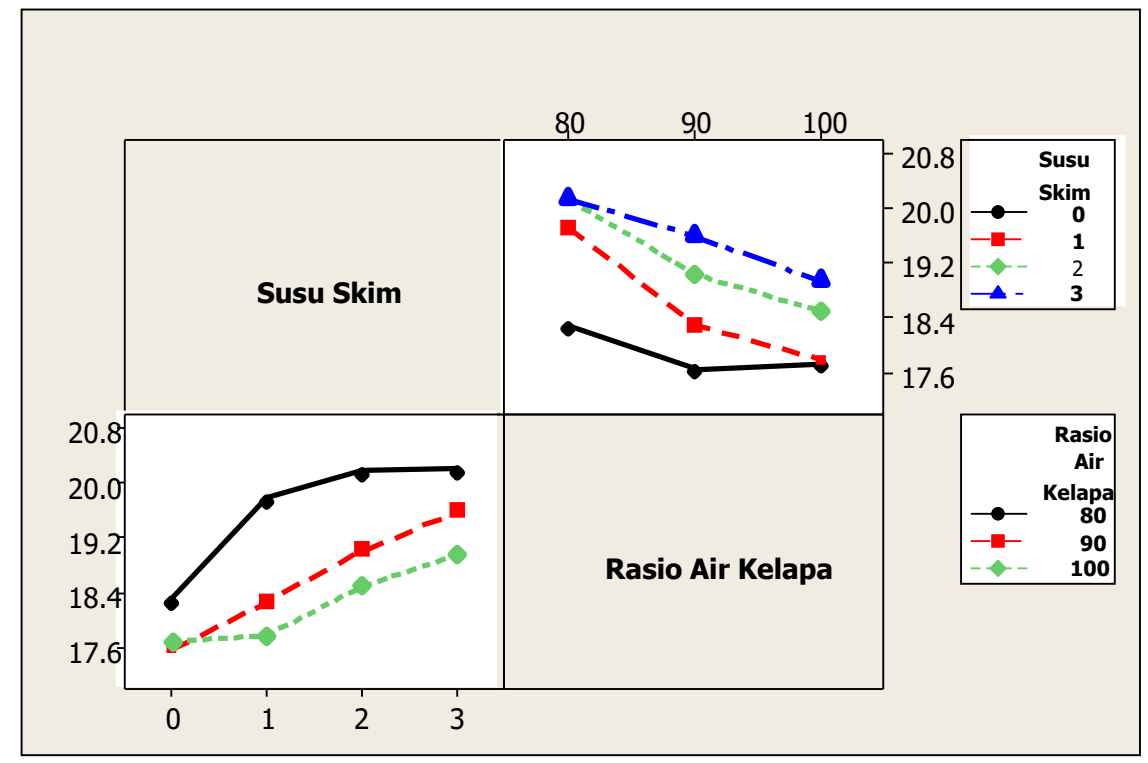

Gambar 3. Pengaruh Rasio Air kelapa Sari wortel dan Penambahan Susu Skim terhadap Padatan Susu tanpa Lemak Minuman Probiotik

Walaupun secara statistik susu skim dan rasio air kelapa sari wortel tidak mempengaruhi kadar padatan susu tanpa lemak, namun dari Gambar 3 terlihat bahwa semakin banyak penggunaan air kelapa kadar total padatan susu tanpa lemak minuman probiotik cenderung semakin menurun, dan semakin banyak penggunaan susu skim kadar total padatan semakin tinggi. Semua produk minuman probiotik pada semua perlakuan yang dicobakan, kadar padatan susu tanpa lemak memenuhi syarat mutu SNI 7552:2009 bahkan kisaran jumlahnya yaitu $17,69-20,15 \%$ berada cukup jauh di atas persyaratan yaitu minimal 3,0\%.

Menurut Ashraf dan Shah (2011), asam organik (termasuk asam laktat) merupakan salah satu jenis total padatan terlarut (TPT) selain gula, pigmen, dan vitamin. Semakin banyak sari wortel yang digunakan, total padatan susu tanpa lemak semakin tinggi. Hal ini disebabkan kandungan gula dari bahan baku wortel sedikit lebih tinggi dari air kelapa (Tabel 1). Semakin tinggi penambahan susu skim, kandungan padatan susu tanpa lemak cenderung semakin meningkat. Padatan ini berasal dari susu skim, dimana susu skim yang digunakan dalam penelitian ini mengandung protein $34,84 \%$ (Tabel 1). Dalam proses fermentasi, protein diuraikan menjadi molekul sederhana dan larut dalam air seperti asam amino dan pepton. Menurut Yanuar dan Sutrisno (2015) sisa sukrosa, laktosa, dan pemecahan protein menjadi molekul sederhana yang ada, dan asam laktat yang terbentuk akan terhitung sebagai total padatan terlarut pada minuman probiotik.

\section{Protein}

Hasil pengujian rata-rata kandungan protein minuman probiotik campuran air kelapa sari wortel berkisar antara 0,10-1,66\% dapat dilihat pada Tabel 2. Setelah dilakukan analisis varians interaksi perlakuan rasio air kelapa sari wortel dan susu skim tidak memberikan 
pengaruh yang nyata $(p>0,05)$. Pengaruh rasio air kelapa sari wortel dan penambahan susu skim terhadap kadar protein minuman probiotik dapat dilihat pada Gambar 4.

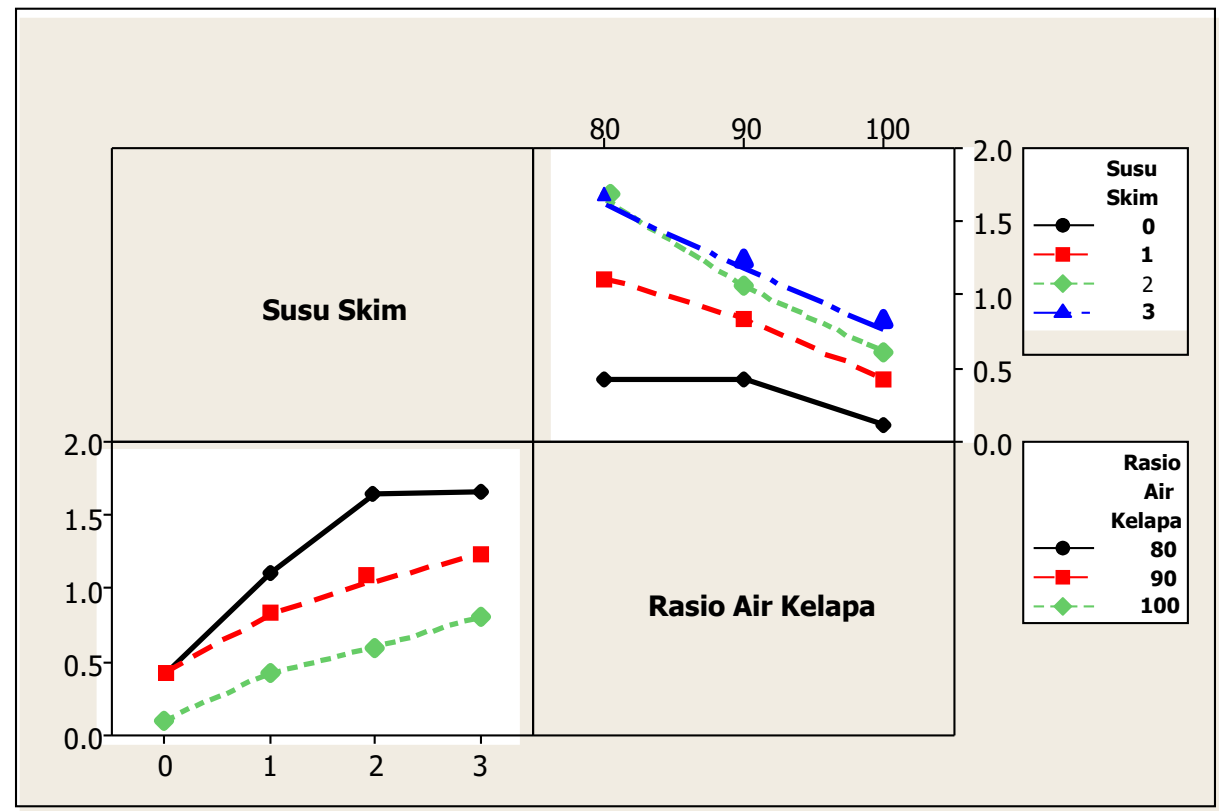

Gambar 4. Pengaruh rasio air kelapa sari wortel dan penambahan susu skim terhadap kadar protein minuman probiotik

Dari Gambar 4 dapat dilihat bahwa kadar protein cenderung semakin menurun dengan semakin banyak penggunaan air kelapa. Menurut Fadro et al. (2015), protein berguna untuk meningkatkan nilai gizi dan sumber nitrogen yang dimanfaatkan oleh bakteri asam laktat untuk pertumbuhannya pada produk fermentasi. Protein ini akan digunakan untuk pembentukan sel bakteri. Walaupun tidak ada perbedaan nyata kadar protein minuman probiotik yang disebabkan oleh interaksi perlakuan penambahan susu skim dan rasio air kelapa sari wortel yang berbeda, namun kecenderungannya kadar protein semakin tinggi dengan makin meningkatnya penambahan susu skim.Dibandingkan dengan persyaratan SNI 7552:2009, kandungan protein produk minuman probiotik tanpa penambahan sari wortel $(100 \%$ air kelapa) tidak memenuhi syarat karena berada di bawah persyaratan yaitu minimum $1 \%$.

\section{Kadar Abu}

Abu adalah zat anorganik sisa hasil pembakaran suatu bahan organik. Penentuan kadar abu berhubungan erat dengan kandungan mineral yang terdapat dalam bahan pangan (Tahar et al., 2017). Hasil pengujian rata-rata kadar abu minuman probiotik campuran air kelapa sari wortel berkisar antara 0,52-0,79\% dapat dilihat pada Tabel 2. Setelah dilakukan analisis varians interaksi perlakuan rasio air kelapa sari wortel dan susu skim tidak memberikan pengaruh yang nyata $(p>0,05)$. Pengaruh rasio air kelapa sari wortel dan penambahan susu skim terhadap kadar abu minuman probiotik dapat dilihat pada Gambar 5. 


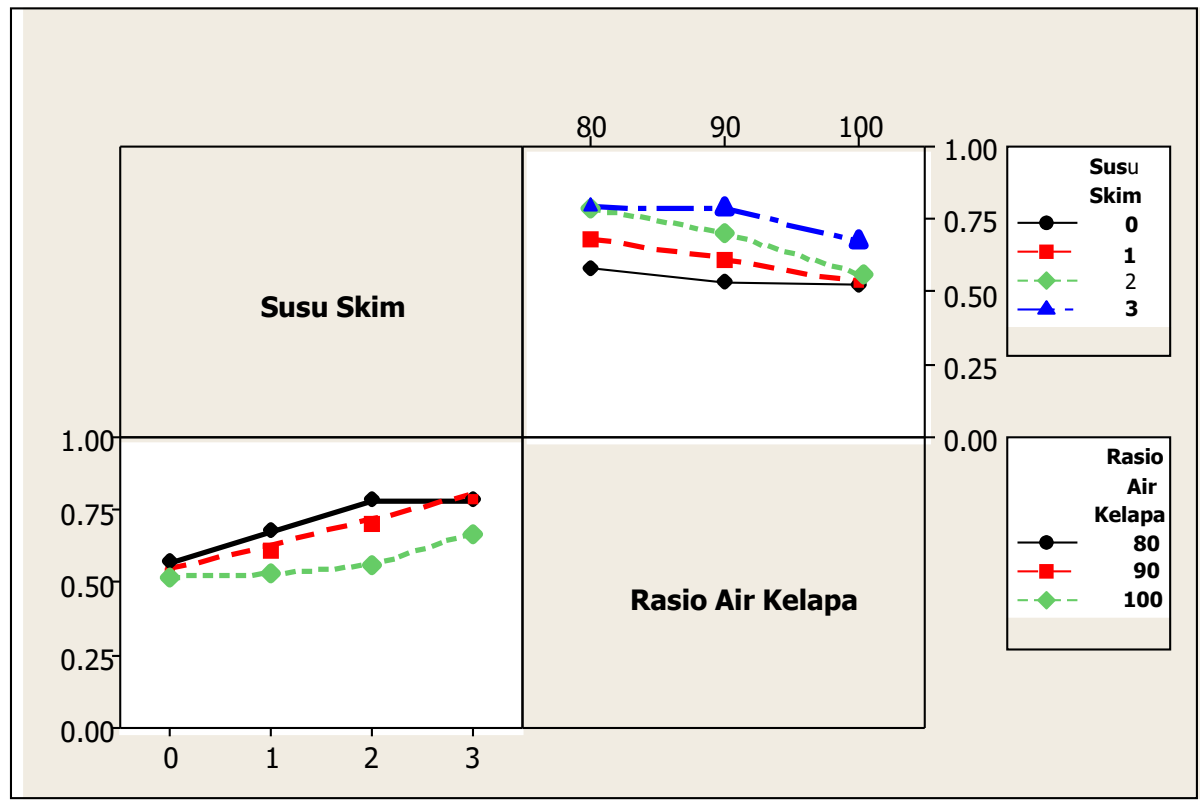

Gambar 5. Pengaruh rasio air kelapa sari wortel dan penambahan susu skim terhadap kadar abu minuman probiotik

Dari Gambar 5 dapat dilihat bahwa semakin banyak air kelapa yang digunakan kadar abu produk minuman probiotik cenderung semakin menurun dan semakin tinggi prosentase susu skim kadar abu cenderung semakin meningkat. Hal ini berarti bahan baku wortel mengandung sedikit lebih banyak mineral dari air kelapa. Dalam American Dairy Products (2014) dinyatakan bahwa susu skim mengandung sejumlah mineral ( $\mathrm{mg} / 100 \mathrm{~g})$, yang terdiri kalsium 1248.00, natrium 494.00, kalium 1674.00, fosfor 993.00, besi 0,40, magnesium 110,00 dan seng sebesar 4,08. Kadar abu produk minuman probiotik campuran air kelapa sari wortel berkisar antara 0,52-0,79\%.

Semua produk minuman probiotik campuran air kelapa sari wortel pada semua level penambahan susu skim memenuhi syarat mutu kadar abu sesuai SNI 7552:2009 karena kadar abunya $<1 \%$.

\section{Keasaman Tertitrasi}

Hasil pengujian rata-rata kadar keasam tertitrasi minuman probiotik campuran air kelapa sari wortel berkisar antara 0,32-1,04\% dapat dilihat pada Tabel 2. Setelah dilakukan analisis varians, perlakuan tunggal rasio air kelapa sari wortel, perlakuan penambahan susu skim, dan interaksi perlakuan rasio air kelapa sari wortel dan susu skim memberikan pengaruh yang nyata terhadap kadar keasaman tertitrasi minuman probiotik $(p<0,05)$. Hasil uji beda Tukey dapat dilihat pada Tabel 2. Hasil uji beda ini menunjukkan bahwa interaksi perlakuan rasio air kelapa sari wortel 100:0 susu skim $0 \%$ berbeda nyata dengan semua perlakuan yang dicobakan, kecuali dengan perlakuan rasio air kelapa sari wortel 90:10 susu skim 0\%. Ratarata kadar keasaman tertitrasi minuman probiotik tertinggi yaitu 1,04\% diperoleh pada perlakuan rasio air kelapa sari wortel 80:20, susu skim 3\% dan terendah pada minuman probiotik menggunakan perlakuan rasio air kelapa sari wortel 100:0, susu skim $0 \%$ yaitu ratarata $0,32 \%$. Pengaruh rasio air kelapa sari wortel dan penambahan susu skim terhadap kadar keasaman tertitrasi minuman probiotik dapat dilihat pada Gambar 6. 


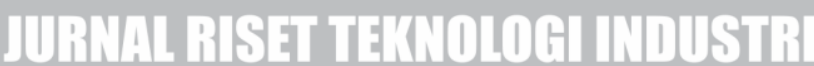

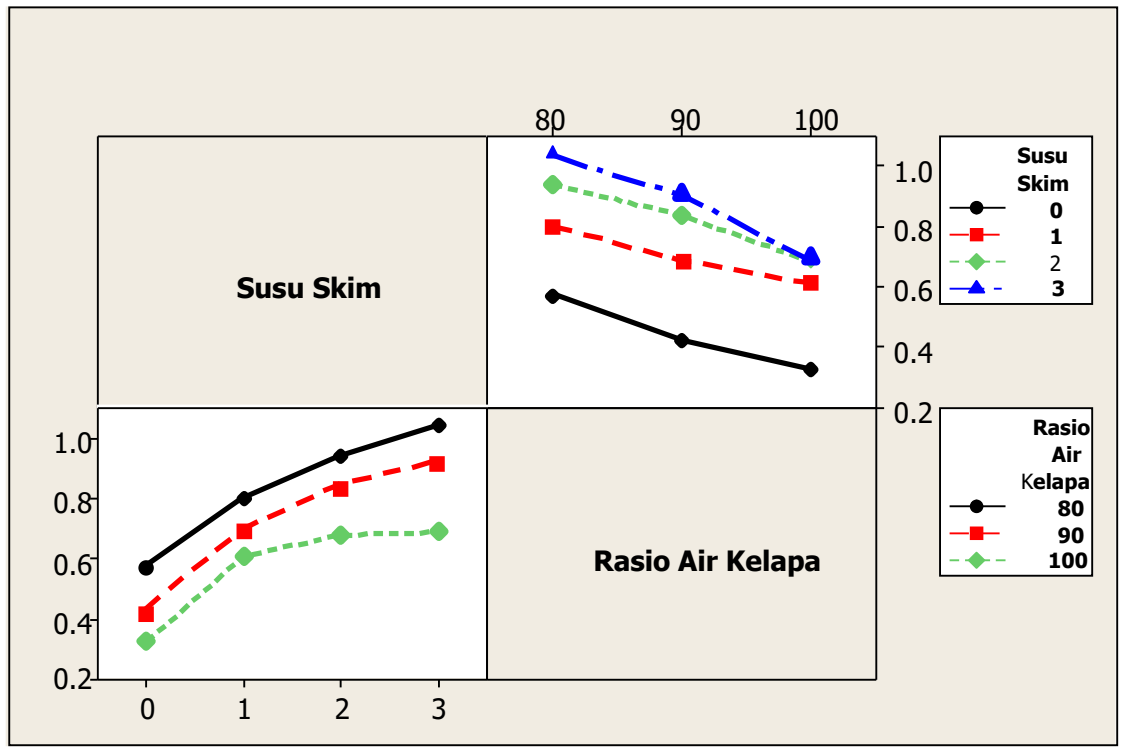

Gambar 6. Pengaruh rasio air kelapa sari wortel dan penambahan susu skim terhadap kadar keasaman tertitrasi minuman probiotik

Dari Gambar 6 dapat dilihat bahwa kadar keasaman tertitrasi produk minuman probiotik semakin menurun dengan semakin bertambahnya jumlah air kelapa, dan semakin meningkat dengan semakin meningkatnya prosentase susu skim yang digunakan. Hal ini berhubungan atau berbanding lurus dengan total padatan susu tanpa lemak dari produk minuman probiotik campuran air kelapa sari wortel yang diperoleh dalam penelitian ini (Gambar 3). Apabila terjadi peningkatan total padatan maka keasaman tertitrasi akan meningkat (Fadro et al., 2015). Total padatan susu tanpa lemak merupakan bahan kering dari produk minuman fungsional yang terdiri dari karbohidrat dan protein. Karbohidrat merupakan sumber energi bagi bakteri asam laktat untuk pertumbuhannya yang menghasilkan zat metabolit berupa asam laktat. Asam laktat ini yang mengakibatkan terjadi peningkatan kadar keasaman tertitrasi. Selain itu berhubungan dengan kandungan protein dan laktosa dari susu skim. Semakin tinggi level susu skim yang ditambahkan semakin banyak protein susu dan jumlah laktosa dari susu skim yang dapat digunakan dan difermentasi oleh bakteri $L$. casei menghasilkan asam laktat sehingga kadar keasaman tertitrasi cenderung semakin meningkat. Kandungan protein susu skim yang digunakan dalam penelitian ini adalah 34,84 \%, sesuai dengan persyaratan mutu susu skim. Menurut American Dairy Products (2014), kadar protein susu skim adalah sebesar 34,0-37,0 $\%$ dan kadar laktosa sebesar 49,5-52,0 \%. Rata-rata produk minuman probiotik campuran air kelapa sari wortel memenuhi syarat mutu kadar keasaman tertitrasi sesuai SNI 7552: 2009 yaitu $0,2-0,9 \%$.

\section{Jumlah Kultur Starter BAL}

Hasil pengujian rata-rata jumlah kultur starter bakteri asam laktat minuman probiotik campuran air kelapa sari wortel berkisar antara 1,43 x 109-7,7 x $10^{9}$ dapat dilihat pada Tabel 2. Setelah dilakukan analisis varians interaksi perlakuan rasio air kelapa sari wortel dan susu skim tidak memberikan pengaruh yang nyata $(p>0,05)$. Pengaruh rasio air kelapa sari wortel dan penambahan susu skim terhadap jumlah kultur starter BAL minuman probiotik dapat dilihat pada Gambar 7. 


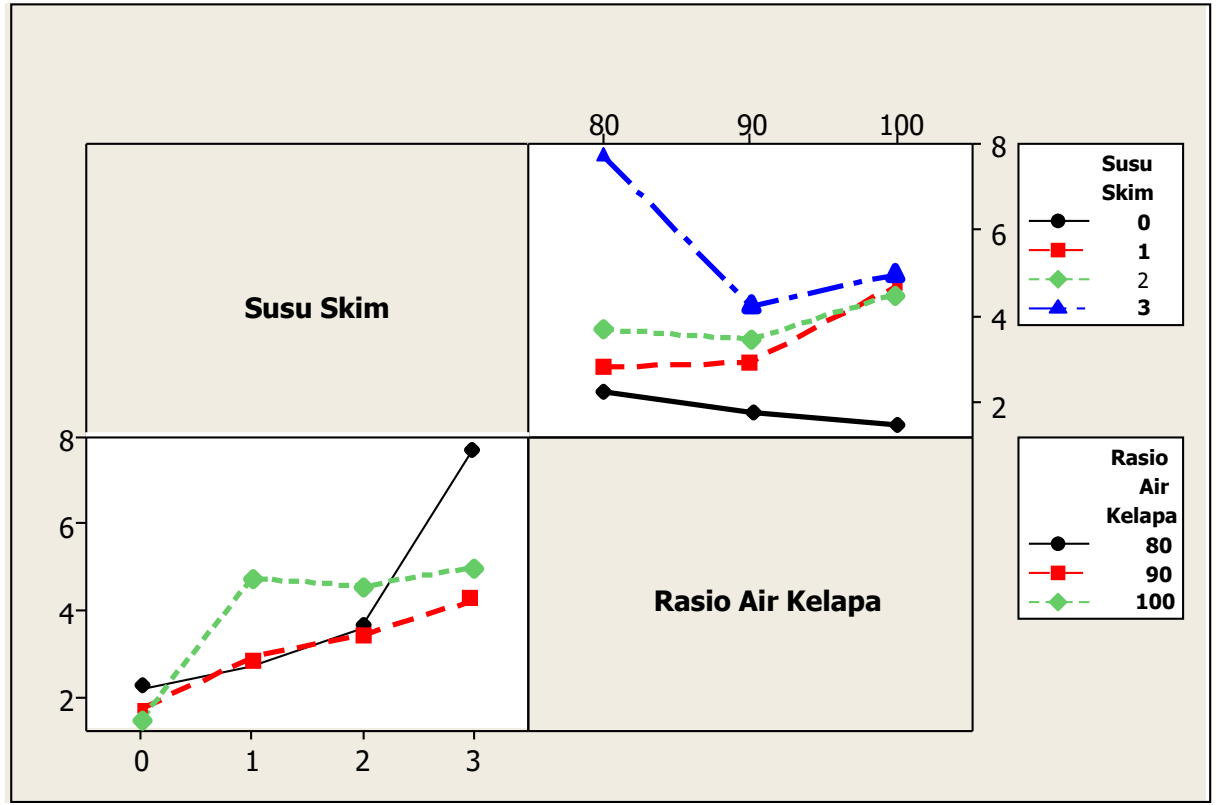

Gambar 7. Pengaruh rasio air kelapa sari wortel dan penambahan susu skim terhadap jumlah kultur starter BAL minuman probiotik

Walaupun dari hasil analisis varians perlakuan rasio air kelapa sari wortel dan susu skim tidak secara nyata mempengaruhi jumlah kultur sarter BAL, namun dari Gambar 7 dapat dilihat bahwa semakin tinggi level susu skim yang ditambahkan jumlah kultur starter bakteri asam laktat cenderung semakin meningkat. Sedangkan untuk perlakuan perbandingan air kelapa dan sari wortel, semakin tinggi prosentase sari wortel, jumlah kultur starter bakteri asam laktat cenderung semakin meningkat pula. Hal ini disebabkan makin tinggi level susu skim dan prosentase sari wortel, semakin banyak sumber makanan bagi bakteri L. Casei yang dapat digunakan baik untuk metabolisme maupun untuk pembelahan sel. Menurut Septiani et al. (2013) semakin banyak susu skim yang digunakan, semakin banyak kandungan laktosa yang dapat dimanfaatkan oleh bakteri asam laktat $L$. casei. Bakteri asam laktat merupakan jenis bakteri yang sangat penting dalam pengolahan minuman probiotik. Mutu minuman probiotik juga sangat ditentukan oleh jumlah BAL yang terdapat pada minuman tersebut (Fadro et al., 2015). Jumlah kultur starter BAL minuman probiotik yang dihasilkan dari semua perlakuan yang dicoba memenuhi syarat mutu SNI 7552: 2009 karena di atas nilai yang disyaratkan yaitu minimal $1 \times 10^{6} \mathrm{koloni} / \mathrm{ml}$.

\section{Kadar Mineral} Tabel 3.

Kadar mineral minuman probiotik campuran air kelapa sari wortel dapat dilihat pada

Tabel 3. Kadar Mineral Minuman Probiotik Campuran Air Kelapa dan Sari Wortel.

\begin{tabular}{ccccc}
\hline \multirow{2}{*}{ No. } & \multirow{2}{*}{ Mineral (ppm) } & \multicolumn{3}{c}{ Air Kelapa : Sari Wortel } \\
\cline { 3 - 5 } & $\mathrm{K}$ & $100: 0$ & $90: 10$ & $80: 20$ \\
\hline 1 & $\mathrm{Na}$ & 3050,18 & 3088,04 & 4684,89 \\
2 & $\mathrm{Ca}$ & 65,95 & 469,31 & 626,04 \\
3 & $\mathrm{Mg}$ & 371,45 & 26,28 & 27,13 \\
4 & $\mathrm{Fe}$ & 506 & 435,52 & 489,36 \\
5 & & & & 1523 \\
\hline
\end{tabular}


Tabel 3 menunjukkan kandungan mineral produk minuman fungsional campuran air kelapa dan sari wortel. Dari Tabel 3 dapat dilihat bahwa produk minuman masih mengandung cukup mineral walaupun dibandingkan dengan bahan bakunya mengalami penurunan atau ada yang hilang pada waktu pengolahan produk. Sedangkan untuk bahan baku susu skim tidak dilakukan pengujian kandungan mineral.

\section{Pengujian Organoleptik}

Hasil pengamatan organoleptik produk minuman fungsional campuran air kelapa sari wortel, sesuai acuan SNI 7552:2009 dapat dilihat pada Tabel 4.

Tabel 4. Hasil Pengamatan Organoleptik Minuman Fungsional Campuran Air Kelapa dan Sari Wortel.

\begin{tabular}{|c|c|c|c|c|c|c|c|c|c|c|c|c|}
\hline \multirow{3}{*}{$\begin{array}{l}\text { Susu } \\
\text { Skim } \\
(\%)\end{array}$} & \multicolumn{12}{|c|}{ Rasio Air Kelapa dan Sari Wortel } \\
\hline & \multicolumn{4}{|c|}{$100: 0$} & \multicolumn{4}{|c|}{$90: 10$} & \multicolumn{4}{|c|}{$80: 20$} \\
\hline & $P$ & $\mathrm{~B}$ & $\mathrm{R}$ & $\mathrm{H}$ & $P$ & B & $\mathrm{R}$ & $\mathrm{H}$ & $P$ & $\mathrm{~B}$ & $\mathrm{R}$ & $\mathrm{H}$ \\
\hline 0 & Cair & $\begin{array}{l}\text { Normal } \\
\text { (khas } \\
\text { yogurt + } \\
\text { air } \\
\text { kelapa) }\end{array}$ & $\begin{array}{c}\text { Asam } \\
\text { manis } \\
\text { yogurt } \\
+ \text { khas air } \\
\text { kelapa }\end{array}$ & $\begin{array}{c}\text { Agak } \\
\text { homogen } \\
\text { (sedikit } \\
\text { sekali } \\
\text { gumpalan) }\end{array}$ & Cair & $\begin{array}{c}\text { Normal } \\
\text { (khas } \\
\text { yogurt) }\end{array}$ & $\begin{array}{l}\text { Asam } \\
\text { manis } \\
\text { (khas } \\
\text { yogurt) }\end{array}$ & $\begin{array}{c}\text { Kurang } \\
\text { homogen }\end{array}$ & Cair & $\begin{array}{l}\text { Normal } \\
\text { khas } \\
\text { yogurt + } \\
\text { wortel }\end{array}$ & $\begin{array}{c}\text { Asam } \\
\text { manis khas } \\
\text { yogurt }+ \\
\text { rasa wortel }\end{array}$ & $\begin{array}{c}\text { Kurang } \\
\text { homogen }\end{array}$ \\
\hline 1 & Cair & $\begin{array}{l}\text { Normal } \\
\text { (khas } \\
\text { yogurt } \\
+ \text { air } \\
\text { kelapa) }\end{array}$ & $\begin{array}{c}\text { Asam } \\
\text { manis } \\
\text { yogurt } \\
+ \text { +khas air } \\
\text { kelapa }\end{array}$ & $\begin{array}{c}\text { Agak } \\
\text { homogen } \\
\text { (sedikit } \\
\text { gumpalan) }\end{array}$ & Cair & $\begin{array}{l}\text { Normal } \\
\text { (khas } \\
\text { yogurt) }\end{array}$ & $\begin{array}{c}\text { Asam } \\
\text { manis } \\
\text { (khas } \\
\text { yogurt) }\end{array}$ & $\begin{array}{l}\text { Kurang } \\
\text { homogen }\end{array}$ & Cair & $\begin{array}{l}\text { Normal } \\
\text { khas } \\
\text { yogurt + } \\
\text { wortel }\end{array}$ & $\begin{array}{c}\text { Asam } \\
\text { manis khas } \\
\text { yogurt }+ \\
\text { rasa wortel }\end{array}$ & $\begin{array}{c}\text { Kurang } \\
\text { homogen }\end{array}$ \\
\hline 2 & Cair & $\begin{array}{l}\text { Normal } \\
\text { (khas } \\
\text { yogurt + } \\
\text { air } \\
\text { kelapa) }\end{array}$ & $\begin{array}{c}\text { Asam } \\
\text { manis } \\
\text { yogurt } \\
+ \text { khas air } \\
\text { kelapa }\end{array}$ & $\begin{array}{c}\text { Agak } \\
\text { homogen } \\
\text { (sedikit } \\
\text { gumpalan) }\end{array}$ & Cair & $\begin{array}{l}\text { Normal } \\
\text { (khas } \\
\text { yogurt) }\end{array}$ & $\begin{array}{c}\text { Asam } \\
\text { manis } \\
\text { (khas } \\
\text { yogurt) }\end{array}$ & $\begin{array}{l}\text { Kurang } \\
\text { homogen }\end{array}$ & Cair & $\begin{array}{l}\text { Normal } \\
\text { khas } \\
\text { yogurt + } \\
\text { wortel }\end{array}$ & $\begin{array}{c}\text { Asam } \\
\text { manis khas } \\
\text { yogurt }+ \\
\text { rasa wortel }\end{array}$ & $\begin{array}{c}\text { Kurang } \\
\text { homogen }\end{array}$ \\
\hline 3 & Cair & $\begin{array}{l}\text { Normal } \\
\text { (khas } \\
\text { yogurt + } \\
\text { air } \\
\text { kelapa) }\end{array}$ & $\begin{array}{c}\text { Asam } \\
\text { manis } \\
\text { yogurt } \\
+ \text { khas air } \\
\text { kelapa }\end{array}$ & $\begin{array}{c}\text { Agak } \\
\text { homogen } \\
\text { (sedikit } \\
\text { gumpalan) }\end{array}$ & Cair & $\begin{array}{l}\text { Normal } \\
\text { (khas } \\
\text { yogurt) }\end{array}$ & $\begin{array}{c}\text { Asam } \\
\text { manis } \\
\text { (khas } \\
\text { yogurt) }\end{array}$ & $\begin{array}{l}\text { Kurang } \\
\text { homogen }\end{array}$ & Cair & $\begin{array}{l}\text { Normal } \\
\text { khas } \\
\text { yogurt + } \\
\text { wortel }\end{array}$ & $\begin{array}{c}\text { Asam } \\
\text { manis khas } \\
\text { yogurt }+ \\
\text { rasa wortel }\end{array}$ & $\begin{array}{c}\text { Kurang } \\
\text { homogen }\end{array}$ \\
\hline
\end{tabular}

Ket.: $\quad \mathrm{P}=$ Penampakan, $\mathrm{B}=\mathrm{Bau}, \mathrm{R}=$ Rasa, $\mathrm{H}=$ Homogenitas

Hasil pengamatan organoleptik produk minuman probiotik campuran air kelapa sari wortel, sesuai acuan SNI 7552:2009 dapat dilihat pada Tabel 4. Dari Tabel 4 dapat dilihat bahwa produk minuman probiotik semuanya berbentuk atau mempunyai penampakan cair, mempunyai bau dan rasa khas yogurt dengan bau dan rasa khas dari bahan baku asal yaitu air kelapa dan wortel tetap ada. Namun pada rasio air kelapa sari wortel 80:20, bau dan rasa wortel lebih dominan sehingga bau dan rasa air kelapa tidak secara nyata terbaui dan terasa. Untuk homogenitas terlihat bahwa hampir semua produk masih belum homogen yang ditandai dengan masih adanya gumpalan susu yang tidak bisa tercampur secara homogen. Hal ini disebabkan dalam pembuatan produk minuman probiotik ini belum digunakan bahan penstabil. 


\section{KESIMPULAN DAN SARAN \\ Kesimpulan}

Interaksi perlakuan rasio air kelapa sari wortel dan susu skim hanya berpengaruh terhadap keasaman tertitrasi minuman probiotik. Perlakuan tunggal rasio air kelapa sari wortel berpengaruh pada semua parameter uji kecuali kadar lemak minuman probiotik. Perlakuan tunggal penambahan susu skim hanya berpengaruh terhadap kadar padatan susu tanpa lemak dan keasaman tertitrasi minuman probiotik. Produk minuman probiotik campuran air kelapa yang memenuhi syarat adalah produk minuman campuran air kelapa sari wortel 80:20 susu skim $1 \%$ sehingga menjadi produk terbaik dengan kandungan lemak $0,50 \%$, padatan susu tanpa lemak $19,72 \%$, protein $1,10 \%$, abu $0,68 \%$, keasaman tertitrasi $0,8 \%$, jumlah kultur starter $2,80 \times 10^{9}$, penampakan cair, bau khas yogurt dan wortel, rasa asam khas yogurt dan rasa wortel, namun masih kurang homogen.

\section{Saran}

Perlu melanjutkan penelitian untuk melihat pengaruh bahan penstabil yang sesuai sehingga dapat diperoleh produk minuman fungsional yang homogen dan stabil.

\section{DAFTAR PUSTAKA}

American Dairy Products. 2014. Skim Milk Powder pp. 1-7. Available at: https://www.adpi.org/DairyProducts/DryMilks/SkimMilkPowder/tabid/359/Default.aspx. 9 Mei 2019 (2:56 PM)

Ashraf, R. dan N. P. Shah. 2011. Selective and Differential Enumerations of Lactobacillus delbrueckii sub sp. bulgaricus, Streptococcus thermophilus, Lactobacillus acidophilus, Lactobacillus casei, and Bifidobacterium spp. in yogurt--a review. International Journal of Food Microbiology 149(3): 194-208.

Badan Pusat Statistik. 2015. Provinsi Sulawesi Utara dalam Angka 2015. BPS Provinsi Sulawesi Utara. Manado.

Badan Standardisasi Nasional. SNI 7552:2009 Minuman susu fermentasi berperisa. Badan Standardisasi Nasional. Jakarta.

Data Komposisi Pangan Indonesia - Beranda. 2017. Available at: http://panganku.org/idID/view. 9 Mei 2019 (2:28 PM)

Fadro, F., R. Efendi dan F. Restuhadi. 2015. Pengaruh Penambahan Susu Skim dalam Pembuatan Minuman Probiotik Susu Jagung (Zea mays L.) Menggunakan Kultur Lactobacillus acidophilus. Sagu 14(2): 28-36.

Farnworth, E. R. dan C. P. Champagne. 2015. Production of Probiotic Cultures and Their Incorporation into Foods, Probiotics, Prebiotics, and Synbiotics: Bioactive Foods in Health Promotion (Chapter 20). Elsevier Inc.

Ginting, N. dan E. Pasaribu. 2005. Pengaruh Temperatur dalam Pembuatan Yoghurt dari Berbagai Jenis Susu dengan Menggunakan Lactobacillus bulgaricus dan Streptococcus thermophilus. Journal Agribisnis Peternakan 1(2): 73-77.

Harjana, D. 2013. Kandungan dan Manfaat Wortel untuk Kesehatan. Available at: http://manfaatnyasehat.blogspot.com/2013/07/kandungan-dan-manfaat-worte/untuk. html. 9 Mei 2019 (2:23 PM)

Krisnaningsih, A. T. N. dan A. Efendi. 2015. Pengaruh Penggunaan Level Susu Skim dan Masa Inkubasi pada Suhu Ruang terhadap pH dan Organoleptik Stirred Yogurt. Jurnal Pendidikan dan Pengajaran Eksakta 6(2): 54-63.

Kristiningsih, T., A. F. Robby, A. Puspita, R. Sulistiowati, E. G. Wongkar dan F. Magdalena. 2018. Provinsi Sulawesi Utara dalam Angka 2018. Edited by I. T. Raharto, A. Unonongo, dan F. A. Tarigan. BPS Provinsi Sulawesi Utara. Manado.

Lebaka, V. R., Y. J. Wee, V. R. Narala dan V. K. Joshi. 2018. Development of New Probiotic 
Foods-A Case Study on Probiotic Juices Therapeutic, Probiotic, and Unconventional Foods (Chapter 4). Elsevier Inc.

Mandei, J. H. 2016. Pemanfaatan Blondo sebagai Starter dalam Pembuatan Yogurt. Buletin Palma 16(1): 66-76.

Rindengan, B., S. Karouw, J. Towaha dan R. Hutapea. 2007. Pengaruh Perbandingan Air Kelapa dan Penambahan Daging Kelapa. Jurnal Littri 13(2): 73-82.

Septiani, A. H., Kusrahayu dan A. M. Legowo. 2013. Pengaruh Penambahan Susu Skim pada Proses Pembuatan Frozen Yogurt yang Berbahan Dasar Whey terhadap Total Asam, pH dan Jumlah Bakteri Asam Laktat. Animal Agriculture Journal 2(1): 225-231.

Tahar, N., M. Fitrah dan N. A. M. David. 2017. Penentuan Kadar Protein Daging Ikan Terbang (Hyrundicthys oxycephalus) sebagai Substitusi Tepung dalam Formulasi Biskuit. Jurnal Farmasi FIK 5(4): 251-257.

Yanuar, S. E. dan A. Sutrisno. 2015. Minuman Probiotik dari Air Kelapa Muda dengan Starter Bakteri Asam Laktat Lactobacillus casei. Jurnal Pangan dan Agroindustri 3(3): 909-917.

Zubaidah, E., E. Saparianti dan M. Mawardhani. 2005. Effect of Carrot Juice Substitution and Fermentation Condition on the Characteristics of LAB-Fermented Milk Drink. Jurnal Teknologi Pertanian 6(2): 93-100. 